№. 2 の耳栓は成形型のため個人差が大きく，装着方法 による有意差は認めなかった。№.3 の耳栓は装着方法 により有意差が一番大きく， No. 4 の耳栓は，有意差は 認めるものの一定の遮音効果が得られた。【まとめ〕耳 栓を選択するにあたっては，作業場の状況を踏まえ，個 人個人にあった耳栓を数種類の中から選び，耳栓によっ ては正しい装着方法の指導も重要である。

\section{4. 企業内労街衛生教育活動について}

○南 勉, 松元庸子, 山田誠二 （松下産業衛生科学センター）

当センターでは, 昭和 56 年から有害業務従事者に対 する従来型の労衝衛生教育を展開する一方, 昨年度は, 全松下グループ事業場の安全衛生関係者（人事担当責任 者・実務担当者・環境管理担当者・医師・保健看護職 等）を対象に，最近とみに必要性を増している産業衛生 に関するより専門的で体系的な研修（産業衛生勉強会） を全国規模で開催した。これら企業内に打ける労衝衛生 教育活動の取り組みについて紹介する。

労衝衛生管理活動の基本は，教育にあるといえる，事 業場における労衝衛生活動において重要な役割を担って いるのが, 衛生管理に携わる専門スタッフであり, 彼らが より専門的知識を高め, 実践的活動に結びつく, 体系づけ られた教育が求められている. 今後は, 更に充実した内 容で, 即戦力に繫がる教育を展開していく予定である.

\section{5. 継続保健指導による生活習慣変容の検討について}

○竹岡和子, 奥田貴子, 上田美代子, 系井重幸 (賏近畿健康管理センター大阪事業部健康指導課)

健康診断の事後指導として, 当社の保健指導基準値に 準じて対象者をリストアップし，保健指導を実施してい る. 今回，保健指導導入加ら 4 年目を迎える S 事業場 において, 平成 6 年度（初年度）の保健指導対象者 131 名について，調査をした，その内，継続して指導を受け たものと受けていない者について，9年度までの検査デ 一夕上生活習慣の変化について面接内容や健診時の問診 票より検討した（ 9 年度の面接内容も含んだ）.

その結果, 9 年度の状况は, 対象者 67 名 (51\%), 対象 外 22 名 $(17 \%)$ ，健診末受診者 42 名 (32\%) であった。 次に，継続保健指導者 6 名についてみると，継続して指 導を受けていない７名に比べ，生活習慣が経年的に改善 しているケースが多く，それに伴いデー夕が改善傾向で あった，そのため，今後もできる限り，継続的なつォ ローを数多く実施することが必要であると考えられた。

\section{6. 肥満者およひ榶尿病に対する 3 ヶ月間の企業内栄養 教育の効果について}

○伊藤克之, 志辺 好, 木下藤寿, 太田千佳代,
中村吉成，臀川明義，岩根幹能，茂原 治

（和歌山健康センター）

〔目的〕企業における健康づくりは，生活の質の向上 や，生産性の向上に結びっくような施策が求められる。 そこで, 病態の改善を目的として, 肥満及び糖尿病を 伴った従業員を対象に栄養教育を行った。

〔方法〕肥満群の対象は，標準体重の $120 \%$ 以上のも の（男性 16 名，平均年齢 $50 \pm 6$ ）, 桾尿病群の対象は 健康診断の結果耐糖能異常々判断されたもの（男性 13 名，平均年齢 $51 \pm 5$ ）とした。

指導は月 1 回の栄養教育を 3 回実施し，教室前後で身 体及び血液㭘査を行った。

〔結果〕体重や％fat は両群之む教育前に比べ有意に 減少した，血圧は糖尿病群でのみ改善が認められた。 ンスリン感受性の改善は糖尿病群でのみ有意に改善した。

(考察) 糖尿病群之肥満群では教室後の効果に違いが 見られたが，それは，対象者の個人特性や指導に対する 本人の取り組み姿勢などが原因だと考えられる。しかし ながら，今回の指導で両群に改善が見られたことは，本 教室の有效性を示唆するものである。

\section{7. 某電機メーカーにおける労働者の運動習慣について} ○村上彰善, 豊田直子, 日馬久美子, 千田恭子, 宮上浩史，山田誠二，藤木幸婎 （松下産業衛生科学センター）

当センターでは「運動アドバイスシステム」を作成し， 運動機能検查・生活状況調査をむとに 7 年間にわたって 健康指導を行ってきた，本研究では，労働者の運動習慣， 特に運動種目が性別・年齢によってどのような傾向にあ るのか分析・検討を試みた。

年齢上ともに瞬発的な動きを伴う集団的または対人的 な対戦型の種目から，瞬発的な動きを伴わない個人的な 目的達成型の種目へと移行している。また，年齢ととも に, 男性ではゴルフ・歩行, 女性では歩行の比率が高く なっている，男性のゴルフは，社交的な手段として，女 性では，家事労㗢などの時間的制約によって，手軽に一 人であできる歩行が多くなっていると考えられる。この ような結果をふまえ，性別・年齢に応じた運動種目を提 示することにより，安全に楽しく継続してもらうことが 必要である。

\section{8. 問題飲酒行動を決定する迹伝・環境要因}

○竹下達也, 丸山総一郎, 森本兼丵 （大阪大・医・環境医学）

問題飲酒行動は，アルコールに関連した健康問題の中 であ大きな問題の一つである，日本人は，東洋人に特有 のアルデヒド脱水素䣼素 (ALDH2) の遗伝子多型が高 頻度に存在し，アルコール感受性に大きな個体差がみら 
れること, 中高年男子の飲酒量が多いこと,などの特徴 を有している. 本研究では, 某中規模事業所の男子労㗢 者を対象として，ALDH2多型等の遗伝素因とともに， 日常のストレス量等の諸環境要因が問題飲酒行動に与え る影響について, 解析を行った。 ロジスティック回帰分 析の結果, 高アルコール消費量群, 高い日常いらだち事 得点, $A L D H 2^{*} 1 /^{*} 1$, 中高年が, 高 KAST 得点群の頻 度に有意に影響を及ぼしていた。へルスプロモーション においては，ALDH2*1/*1 遺伝子型，とくにその中高 年群を主なターゲットとして, 問題飲酒対策を立案する 必要がある。また対策としては日常的なストレスに対す る対策が重要であると考えられる.

\section{9. 長期喫煙者に見られる白血球増多症について}

○平野 拓（済生会吹田特養高寿園）

20 数年来, 一企業にて白血球数測定を含む健診を実 施し，単年度および経年観察による鑑別除外診断を行い， 長期喫煙者と白向球増多の関連を認めた。白血球增多に は個人差があり，時期によって変動が見られる，単年度 ごとの白血球增多例のうち，長期喫煙者の占める率は $9,000 / \mathrm{mm}^{3}$ 台では 50 〜 80\%，10,000/m̊n以上では $70 \sim$ $90 \%$ であった２0年間の継続観察では，1日20本末満 の婆煙者では白血球増多は見られなかった。白血球増多 が見られた例では1日の喫煙本数の多いほど，契煙歴 （年数）が長いほど白血球増多の例数および回数が増え る傾向にある．長期喫煙者で初めて白血球增多の見られ た年代は，1日の喫煙本数が 20 本台では喫煙歴 (年数) が 20 年以上（40 歳代）に多く，1日30本以上では喫 煙歴 20 年末満（20歳代，30歳代）にも見られる。一般 健診にて，原因不詳の白血球増多例を見たとき，長期喫 煙者であれば喫煙との関連も疑う必要がある.

\section{第 41 回頸肩腕障害研究会*}

本研究会の内容は上肢作業の認定基準改正問題之，頸 肩腕障害症例收集, 関連国際学会の案内等であった。

\section{第 42 回頸肩腕障害研究会**}

\section{1 、顒肩腕症候群等に関する検討結果報告書について} 井谷 徹 (名市大・医・衛生)

*1997年 4月 11日（金）17：00-19：00, 富山県民会館 世話人：小野雄一郎（藤田保衛大・医・公衛）他

${ }^{* *} 1997$ 年 8 月 9 日 (土) $10: 00-17: 00$, 同志社大学寧静館 (京都)

世話人：小野雄一郎（藤田保衛大・医・公衛）他
標記報告書に対しては，様々な意見が出されている． その主なものを挙げ，それに関する私の意見を以下に述 ベる.

1) 職種や症状などで, 認定される範囲が拡大され た：旧認定基準に該当しない認定事例を考慮して新基準 が作成されたので，認定範囲は拡大されたと考えられる.

2 ）数值基準の根沽が曖昧である：数值で示された基 準は，旧認定基準と同一のあのが多い，それは，認定担 当者加ら現行の基準が有用であるとの声が強いことに加 え，新たな数值を認定するに足る研究成果がないためで ある，ただし，多くの部分に例外規定が設けられており， 運用面で柔軟性を持たせている。数值基準以外の部分も 含め運用状況の点検, 修正が必要であろう.

3）上肢障害という名称が良くない：上肢作業者に発 生する障害という意味であるが，上肢部分の障害という 意味にも捉えられる名称であり，確かに問題だと思う.

\section{2. 労災・公務災害認定の法的意義と上肢作業に基づく 疾病の認定基準}

佐藤克昭（京都法律事務所）

1. 労働災害・公務災害といわれているのは, 労働者 災害補償法・国家公務員災害補償法・地方公務員災害補 償法においてそれぞれ，業務上のあのとして認められた 疾病をいう。あくまでも，その認定は行政機関による行 政処分の形を取ることになる.

2. 認定基準は, 行政の画一的対応の必要性から，行 政機関としての認定作業の基本を定めたあのである. 認 定基準を充足する場合に業務起因性を肯定することは, 専門家会議などの専門的知見を前提にしていることから， 合理性が付与されることに争いはない。

3. 業務起因性を，行政機関が認定基準を前提にして 否定した場合には，その行政処分の妥当性が問われるこ ととなり，行政訴訟により，その業務外の認定を取り消 す裁判が起こされることとなる。

その際には，裁判所における判断としては，認定基準 に拘束されることはない. 裁判においては, 法の規定に 基づいた業務起因性の判断を行う。

\section{3.上肢作業に基づく疾病の認定基準の問題点について}

宇土 博（広島大・医・公衛）

患者の認定・治潦を行う立場からみた新認定基準の主 な問題点は, 以下のように要約される. (1)対象業務が, 事務系作業では OA 機器のみに限定され, ボールペン 複写，伝票整理等がなく偏っている. (2)欧米での職業性 の概念を含む職業性頸肩初障害, 反復性疲労障害等の名 称に対して，新基準の「上肢障害」にはこのような概念 がなく，上肢に限定された不適切な名称が使用されてい る. (3)上腕骨外上顆炎, 时部管症候群等の頻度の低い特 